\title{
sciendo

\section{Empirical Model of Cost Reduction in Local DH Systems. Low Temperature Approach}

\author{
Dagnija BLUMBERGA ${ }^{1 *}$, Raimonds GULBIS ${ }^{2}$, Linda IEVINA $^{3}$, Valdis VITOLINS ${ }^{4}$, \\ Girts VIGANTS ${ }^{5}$, Jevgenijs SELIVANOVS ${ }^{6}$, Dzintars JAUNZEMS ${ }^{7}$ \\ ${ }^{1-7}$ Institute of Energy Systems and Environment, Riga Technical University, \\ Azenes iela 12/1, Riga, LV-1048, Latvia
}

\begin{abstract}
Improving the efficiency of heating systems can give a tremendous contribution towards the EU energy efficiency target for $\mathbf{2 0 3 0}$. Significant heat losses are one of the main disadvantages of the dominating high temperature district heating (DH). Even in summer, the high retention time of water in the network leads to thermal losses from domestic hot water reaching up to about $30 \%$. An empirical model based on experimental data of heat energy consumption in multi-apartment buildings is created for economical optimization of the operation of DH systems. A methodology has been developed that allows estimating the total energy cost savings (including losses) of buildings associated with the reduction of heat loss in the system, by reducing the supply flow temperature, and increasing electricity consumption by increasing the mass flow rate of water in the network.
\end{abstract}

Keywords - Cost reduction; district heating (DH) systems; economical optimization; energy savings; low supply temperature; water capacity in DH systems

\section{INTRODUCTION}

The European Union has set itself a $32.5 \%$ energy efficiency target for 2030 [1]. Improving the efficiency of heating systems can give a tremendous contribution towards this target. Significant heat losses are one of the main disadvantages of the dominating high temperature district heating (DH). Even in summer, the high retention time of water in the network leads to thermal losses from domestic hot water reaching up to about $30 \%$ [2].

By the means of energy efficiency, the topic on low temperature district heating (LTDH) becomes more and more relevant. It is assumed that LTDH will increase its importance in the future, due to its high potential for heat supply and ability to operate on heat from renewables and waste [3]. Lower supply temperatures reduce heat loss, consume less fuel, and have a smaller impact on the environment, due to the minor difference in temperature between the heating network and the surrounding ground [4]. LTDH is especially beneficial for raising the share of renewables in energy, for its supply temperature is suitable for several renewable sources, including resources with not yet fulfilled potential, e.g. industrial excess heat [5], waste [3], geothermal energy [6], etc. Therefore, LTDH is a tool not only to reach energy efficiency targets, but it also contributes to increasing the share of renewables, which is another key goal for the EU.

An LTDH system usually refers to a system of district heat supply network operating in the range between $50{ }^{\circ} \mathrm{C}$ and $70{ }^{\circ} \mathrm{C}$ supply and $25-40{ }^{\circ} \mathrm{C}$ return temperature [7]. Nord et al. [8]

\footnotetext{
* Corresponding author.

E-mail address: dagnija.blumberga@ rtu.lv
} 
found that network heat loss can be reduced by lowering the supply temperature from $80{ }^{\circ} \mathrm{C}$ to $55^{\circ} \mathrm{C}$. Meanwhile, a study by Cai et al. [9] shows that lowering the supply temperature from $70{ }^{\circ} \mathrm{C}$ to $50{ }^{\circ} \mathrm{C}$ in the $\mathrm{DH}$ system can reduce heat losses by $35 \%$. A smaller reduction of heat loss was found by Park et al. [10], when lowering the supply temperature from $65{ }^{\circ} \mathrm{C}$ to $45^{\circ} \mathrm{C}$ gave a reduction of heat loss by $15.6 \%$. Meanwhile, Li and Wang [11] calculated the greatest reduction - by up to $75 \%$ when compared with the medium temperature $\mathrm{DH}$ system.

Some studies indicate that it is possible to maintain a comfort temperature in domestic space even with ultra-low supply temperature of $40^{\circ} \mathrm{C}$ [12] and $45^{\circ} \mathrm{C}$ [13]. Here the question of the $5^{\text {th }}$ generation $\mathrm{DH}$ becomes relevant. $5^{\text {th }}$ generation $\mathrm{DH}$ with ultra-low temperature provides additional values to the $4^{\text {th }}$ generation $\mathrm{DH}$, such as flow temperature close to the ground temperature, the ability to work in heating or cooling mode independently of network temperature, bi-directional and decentralized energy flows [2]. However, it is important to consider that energy efficiency is also determined by a proper design of buildings, which should be suited for particular climatic conditions [14], [15], giving special consideration to the material of the outside wall [16].

Usually, in order to achieve higher energy efficiency, the supply temperatures should be as low as possible. However, while for space heating at a comfortable room temperature can be reached with ultra-low supply temperature, the reduction of supply temperature for domestic hot water can raise sanitary-related issues, like avoidance of Legionella bacteria forming [12].

Although transition to the $4^{\text {th }}$ generation $\mathrm{DH}$ is related to possible costs of modification of heating systems, conversion of district heating grids and readjustment of buildings, it gives more benefits due to a better utilization of low temperature heat sources, lower grid losses, and improved efficiency in the production system [17]. As research shows, LTDH can give additional cost savings when technical innovations in heating systems are applied. Im and Liu [18] used a simulation to show that an auxiliary heat storage pipe can help to maintain stable temperature conditions of supply flow, and therefore save more energy. Sameti and Haghighat [19] demonstrated that additional energy savings in district heating systems can be achieved by expanding heat exchange among several buildings, which can lead to a $25 \%$ reduction in annual costs. Whereas Tunzi et al. [20] investigated the application of LTDH to hydraulic radiators by adjusting temperatures according to demand, and found that it can lead to a discount of $14 \%$ to $16 \%$ in annual energy bills.

\section{Methodology}

\subsection{Energy Balance}

The heat consumption of buildings depends on two parameters: mass flow rate of water in the heating network and temperature difference in the supply and return pipes. It is determined by the equation of heat balance:

$$
Q=c \cdot G \cdot\left(t_{\mathrm{tg}}-t_{\mathrm{atg}}\right),
$$

where

$Q \quad$ Heat consumption, $\mathrm{kW}$;

$c \quad$ Water specific heat, $\mathrm{kJ} /(\mathrm{kg} \cdot \mathrm{K})$;

G Flow-through, kg/s;

$t_{\mathrm{tg}} \quad$ Water temperature in the supply pipelines, ${ }^{\circ} \mathrm{C}$;

$t_{\text {atg }} \quad$ Water temperature in return pipelines, ${ }^{\circ} \mathrm{C}$. 
Heat supply to the building can be achieved by:

- Increasing difference between supply and back flow water temperature;

- Increasing mass flow rate of the water in the network;

- Other solutions: mixing solutions mentioned above to reach an optimal solution for the local situation.

The implementation of the optimization task involves the identification of optimal technological parameters and the search for the lowest costs. Therefore, it is very important to analyse the operating parameters of the local heating system and to find the links between them.

\subsection{Experimental Research for Multi-Apartment Buildings. Kemeri Case}

The experiment was carried out in Kemeri for two multi-apartment building (Fig. 1), where heating systems and hot water consumers are connected to the district heating system.

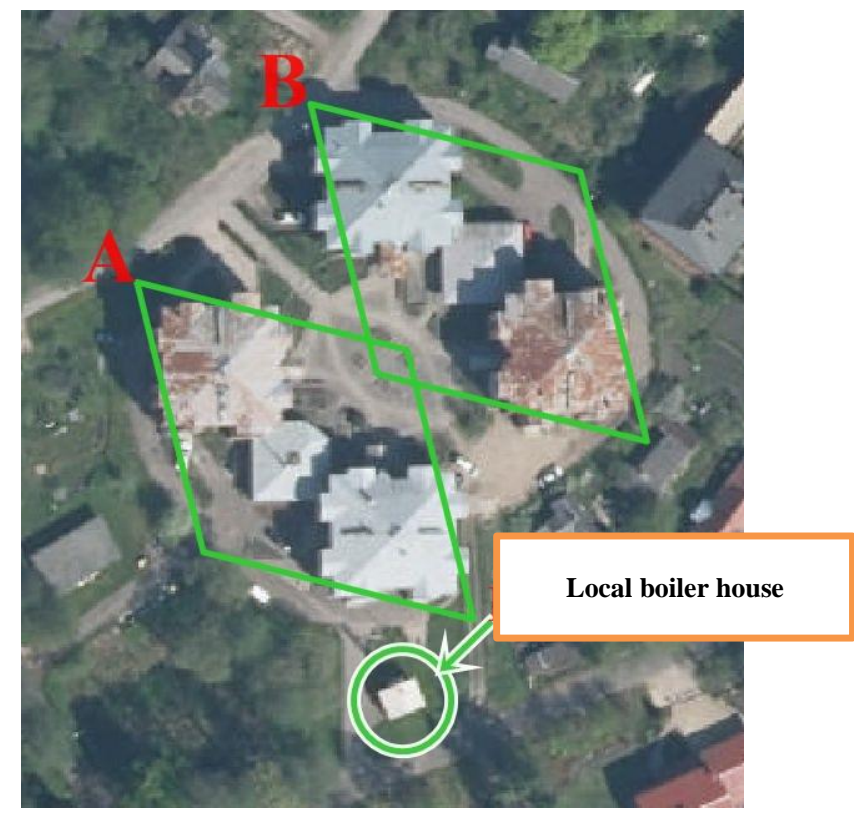

Fig. 1. Location of Kemeri buildings.

The buildings are located very close to each other, forming a square. Brick buildings are built in two pairs. Each pair consists of one two-story building and one three-story building. In the middle between both buildings, there is a one-story unheated auxiliary building as a connecting element.

Each pair of buildings has its own individual heating substation (IHS). Each pair of buildings has 20 apartments and about 54 residents, and a heated area of $1493 \mathrm{~m}^{2}$. Each IHS provides heat supply and the possibility to regulate several settings, e.g. heat curve for building space heating system, night set-back, etc. The local boiler house provides heat energy to a total of 40 apartments with a total heated area of $2986 \mathrm{~m}^{2}$.

The two buildings are supplied with heat by a local boiler house which consists of two heating plants with the power of $350 \mathrm{~kW}$ each. The boiler house is powered by natural gas. 


\subsection{Course of the Study}

The experiment was conducted from February to April 2019, however, monitoring of data already started in November 2019. Each IHS is equipped with a heat meter from "Kamstrup" and a remote meter reading system from "Metlink". The data was collected on supply and return temperatures, water capacity, flow rates and heat consumption in order to find the link between them. The overall steps of the research are presented in Fig. 2.

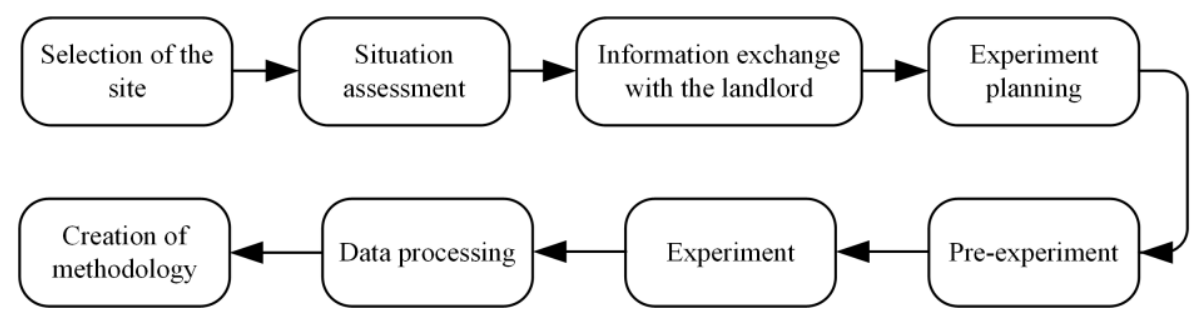

Fig. 2. Steps of the research.

The analysis of the local heating system for one of the pairs of buildings was carried out for 3 periods (see Fig. 3).

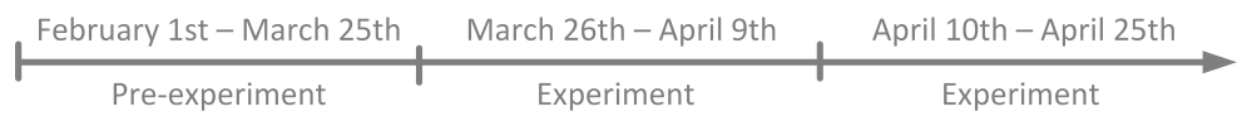

Fig. 3. Experiment time scale.

During the pre-experiment, the supply temperatures in the district heating system was kept as usual with no regulations. Only observations were made during this time.

The first experiment was carried out from March $26^{\text {th }}$ to April $9^{\text {th }}$, when the flow temperature was decreased by $17^{\circ} \mathrm{C}$ to see how it would affect other factors.

The second experiment was carried out from April $10^{\text {th }}$ to April $25^{\text {th }}$, when the flow temperature was decreased by another $5{ }^{\circ} \mathrm{C}$. The course of the experimental part of the research is presented in Table 1.

The requirement was set to reduce indoor temperature during the experiment by no more than $1-2{ }^{\circ} \mathrm{C}$.

TABLE 1. COURSE OF THE EXPERIMENT

\begin{tabular}{lll}
\hline Period & & Flow temperature \\
\hline February & Pre-experiment & Without regulations $\left(\sim 85^{\circ} \mathrm{C}\right)$ \\
March $26^{\text {th }}-$ April $9^{\text {th }}$ & Experiment & Decreased by $17^{\circ} \mathrm{C}$ \\
April $10^{\text {th }}-$ April $21^{\text {th }}$ & Experiment & Decreased by another $5{ }^{\circ} \mathrm{C}$ \\
\hline
\end{tabular}

\section{RESUlts}

For each period, selective data analysis was performed, looking for the influence of independent variables (outdoor air temperature, supply and back-flow temperature and mass flow rate of the water in the network) on the dependent variable (total heat consumption). 


\subsection{Data Analysis}

Changes in the supply and return flow temperatures depending on the outdoor air temperature are illustrated in Fig. 4. The analysis of the data of the supply and back-flow temperature changes shows that the data correlation is good during the pre-experiment. The resulting regression equations can be considered as empirical models and can be used to analyse the results.

In turn, the supply and return flow temperatures during experiment show a weak correlation with outdoor air temperature, which indicates that the return flow temperature is influenced by hot water consumption.

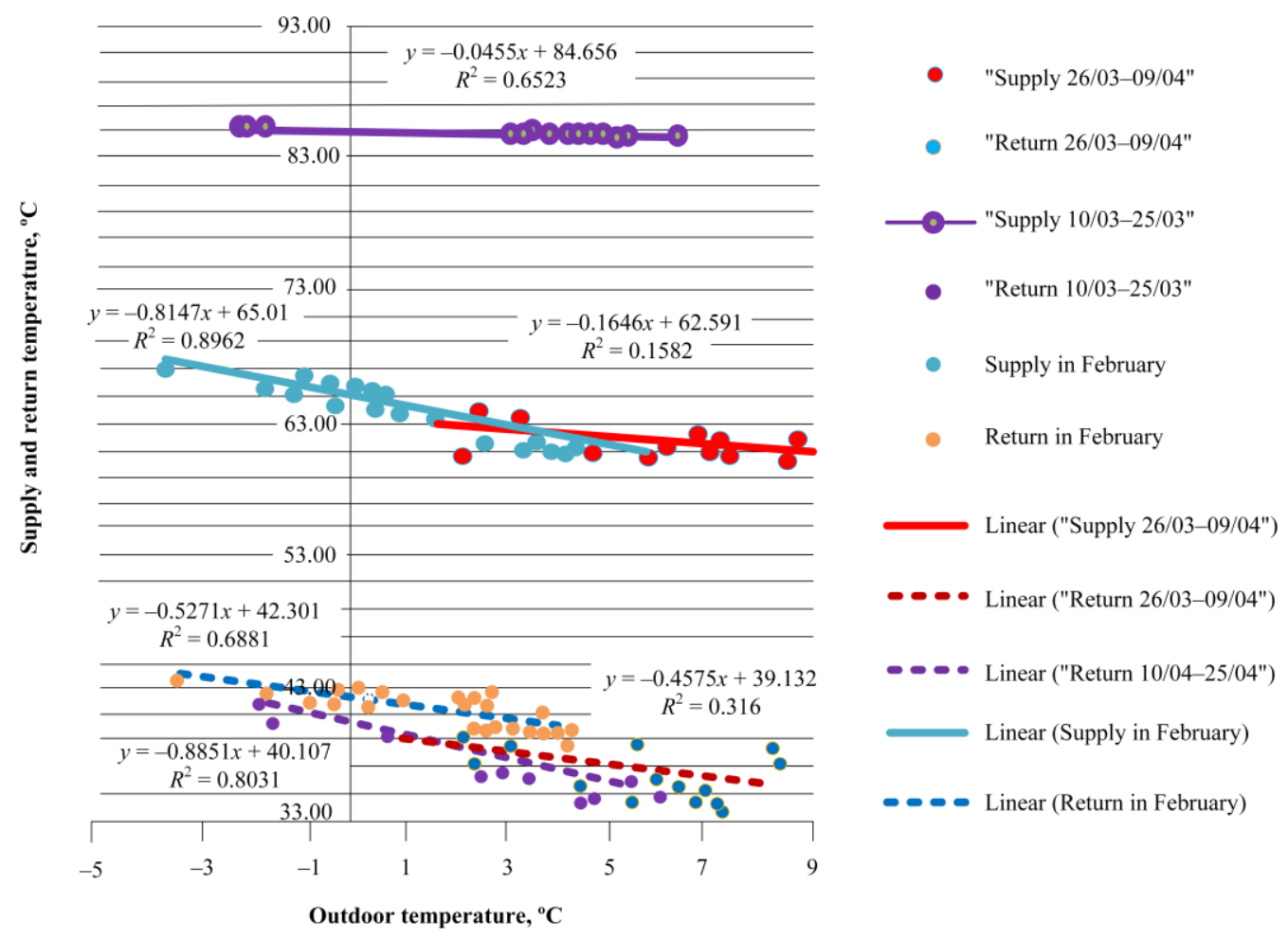

Fig. 4. Supply and return flow temperatures during the pre-experiment and experiment.

The data also shows that the supply flow temperatures during the pre-experiment and experiment do not depend on the outdoor air temperatures which leads to the conclusion that in March, the quantitative regulation with increase or decrease of the mass flow rate was carried out with a constant supply flow temperature, but in February the temperature was relatively low and it changed slightly depending on outdoor temperature. In turn, the return flow temperature practically did not change depending on the supply flow temperature.

All of the above shows that there is no deliberate regulation of heat supply and reduction of heat consumption in buildings. During the experiment, the temperature of the water supply lines was reduced with the hope to reach a temperature decrease of the return pipes. However, this failed because the mass flow rate of the water automatically increased (see Fig. 5). 


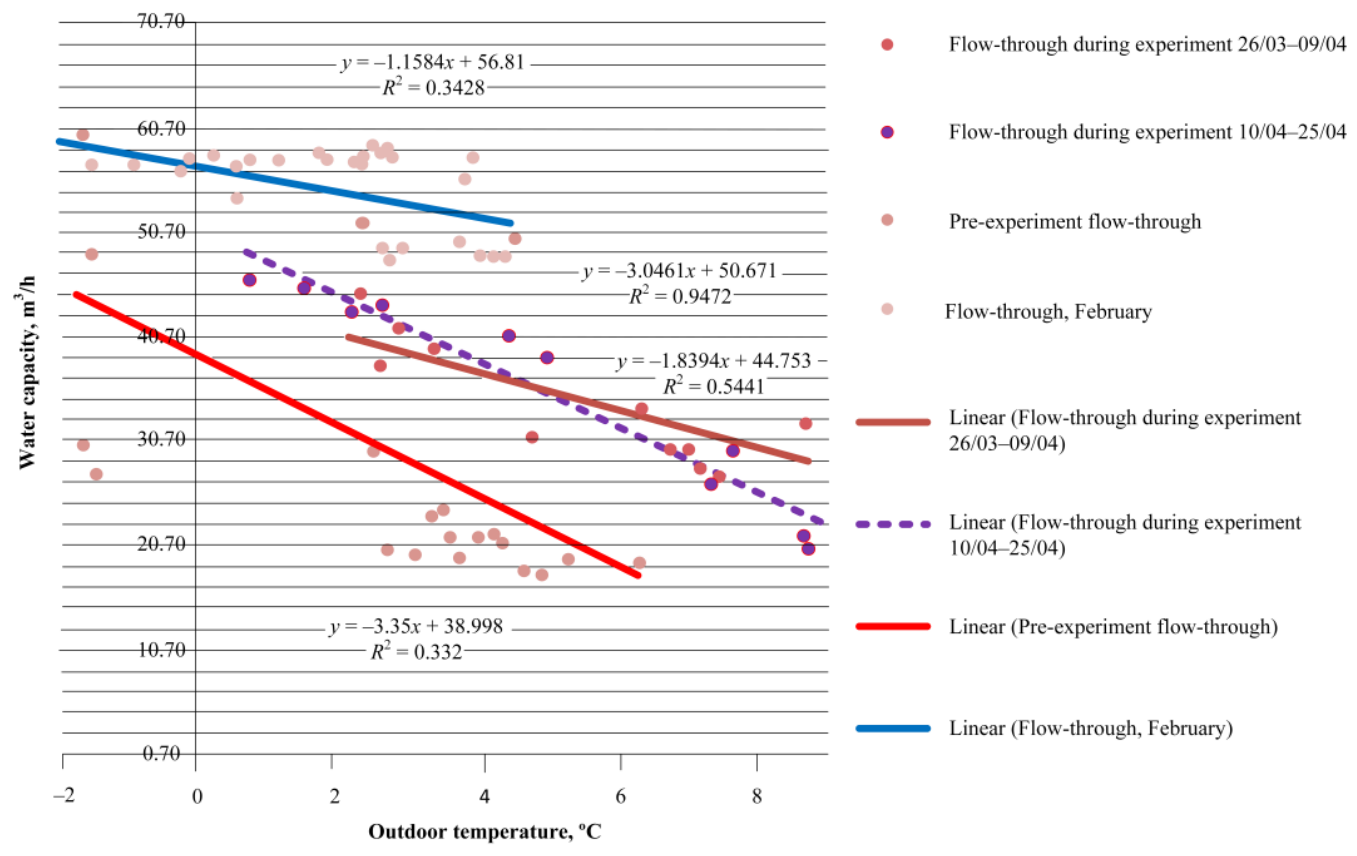

Fig. 5. Changes in the daily mass flow rate $\left(\mathrm{m}^{3} /\right.$ day) during the pre-experiment and experiment.

The results of the analysis are summarized in Fig. 6 and show both a satisfactory data correlation and a large dispersion of data. Therefore, it is possible to conclude that the regulation of the mass flow rate is more incidental. Therefore, the empirical model can only be used for the correlation of good data achieved during the last experiment $\left(R^{2}=0.94\right)$. During the pre-experiment, the dispersion of data $\left(R^{2}=0.33\right.$ and $\left.R^{2}=0.34\right)$ is high, indicating a lack of energy management in the building.

The consumption of heat depending on the mass flow rate in the network is illustrated in Fig. 7. There is good correlation during the pre-experiment period - in February $\left(R^{2}=0.74\right)$ and in March $\left(R^{2}=0.99\right)$. In contrast, during the experiment, the correlation is not as good $\left(R^{2}=0.51\right)$. This may be due to a reduction in the supply flow temperature as it does not change according to the outdoor air temperature. Therefore, the temperature difference was minimally affected. 


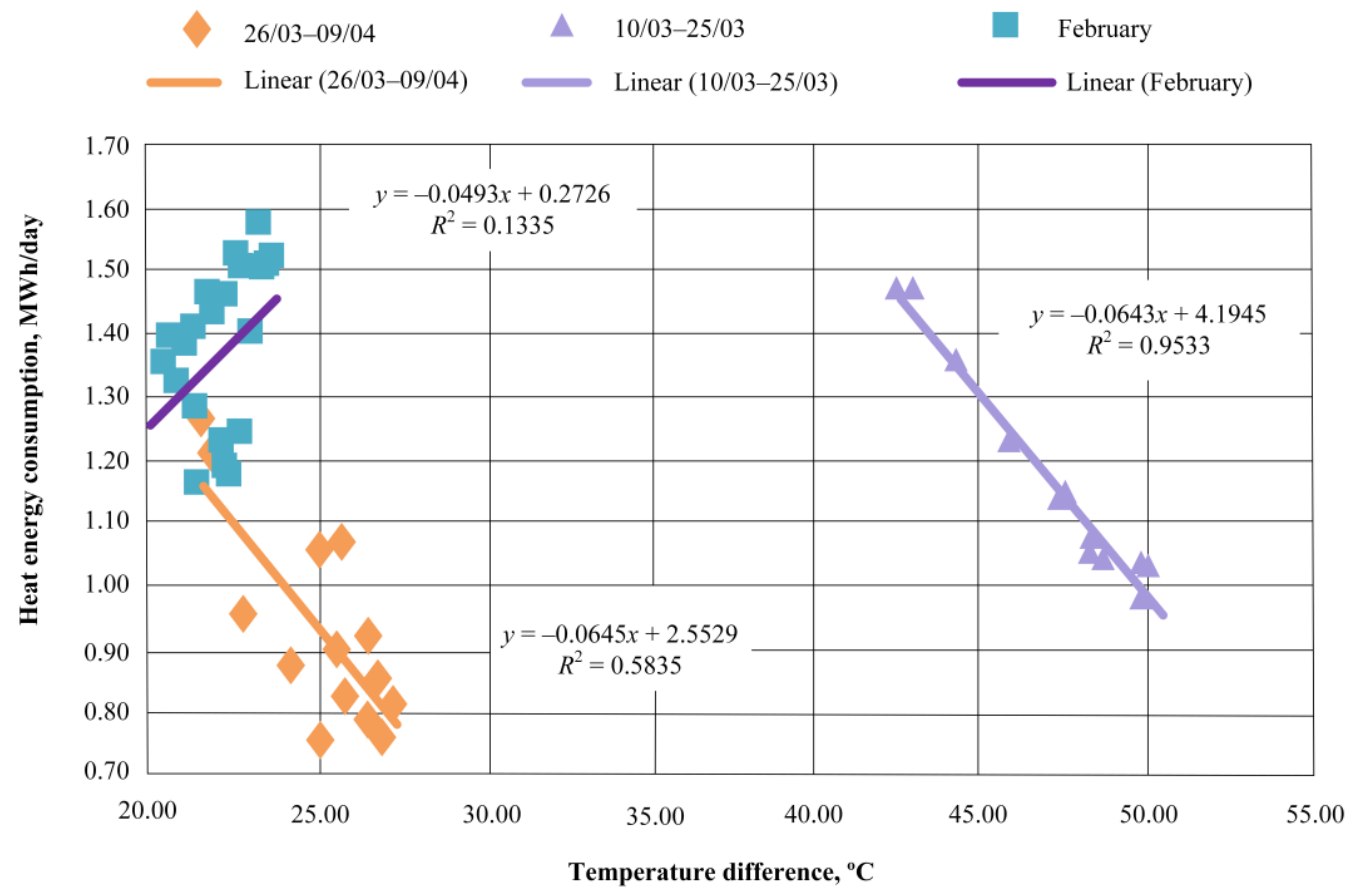

Fig. 6. Heat consumption depending on water temperature difference.

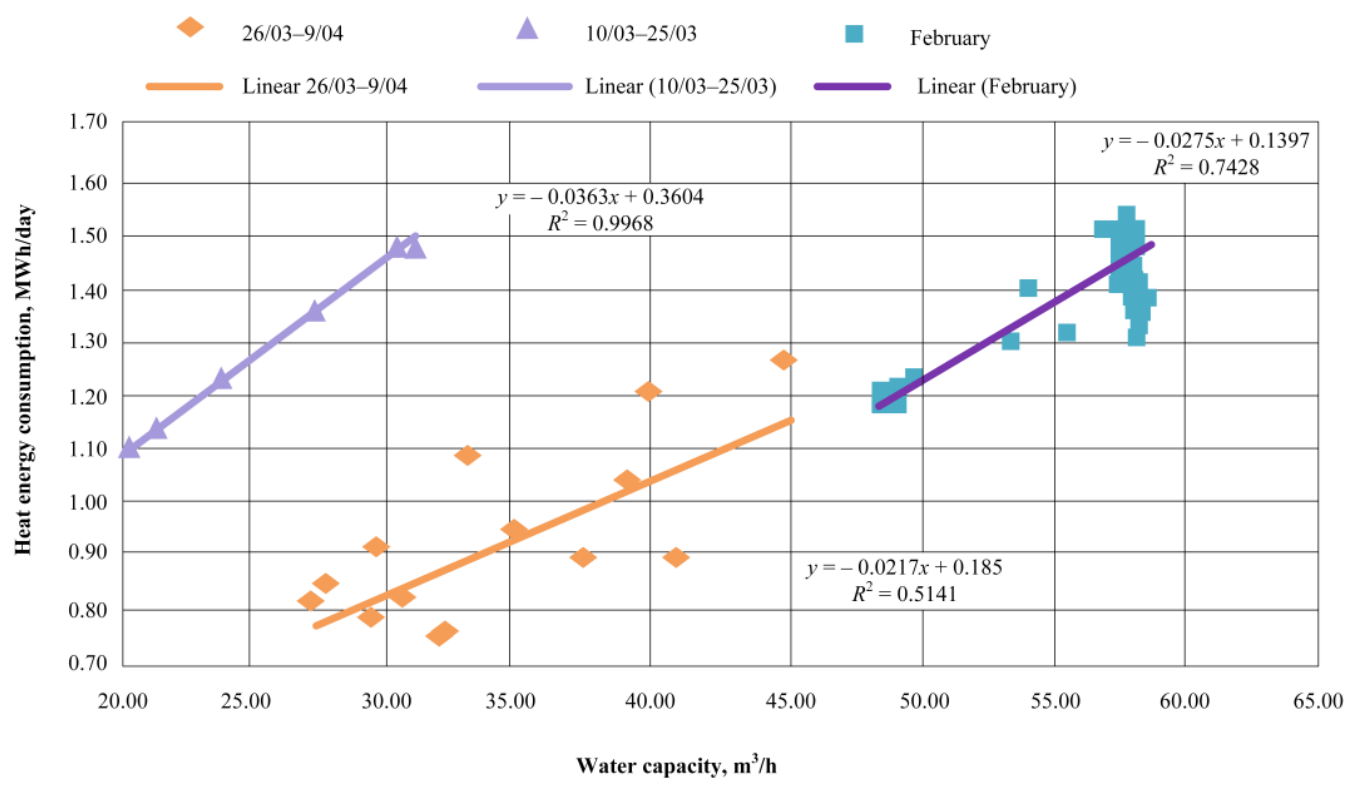

Fig. 7. Heat consumption depending on mass flow rate. 
An interesting picture emerged in the analysis of heat consumption changes versus the temperature difference (see Fig. 6).

During the pre-experiment in February, the temperature difference remained unchanged $\left(R^{2}=0.13\right)$, therefore quantitative regulation, changing the mass flow rate in the system, led to a waste of heat energy in the building (see Fig. 8).

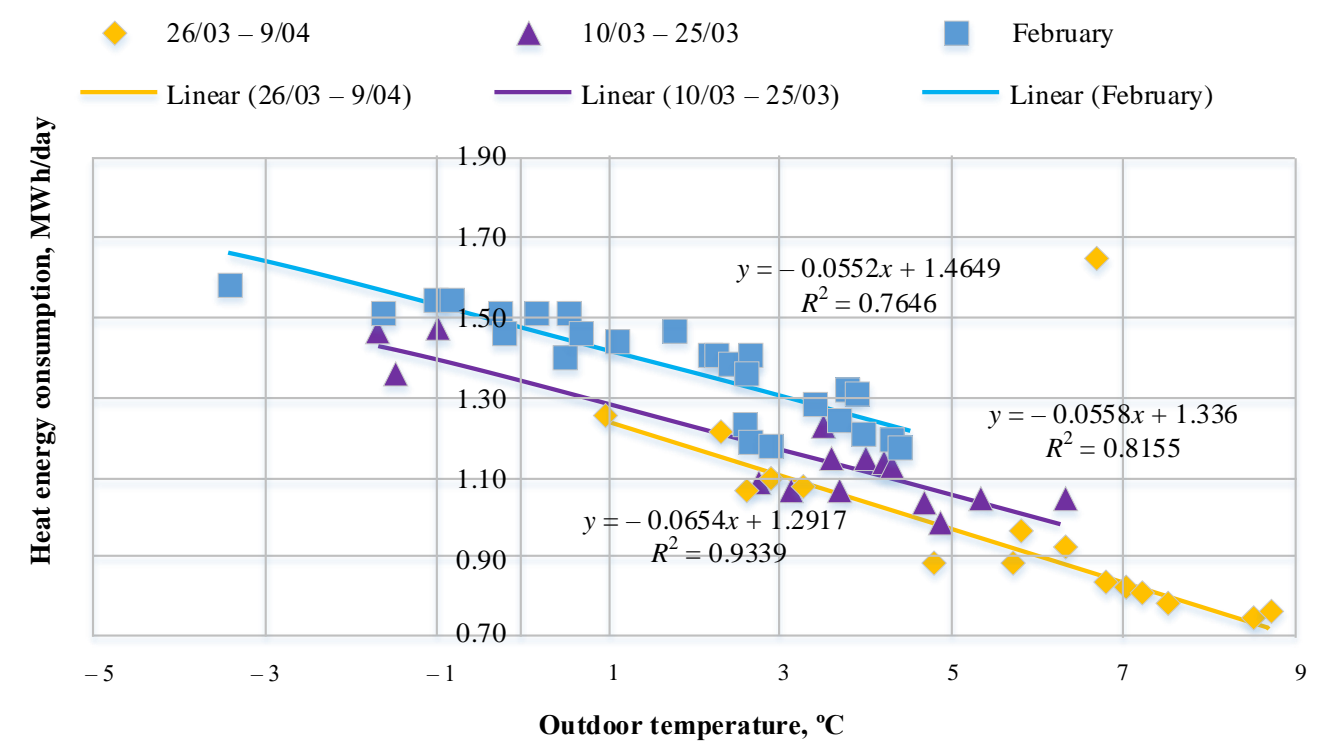

Fig. 8. Heat consumption depending versus outdoor air temperature.

During the pre-experiment period in March, a greater temperature difference and good data correlation were observed $\left(R^{2}=0.95\right)$. However, the regulation of heat supply is even more pronounced: the temperature difference increases as the heat consumption decreases, which increases the overall operating costs of the system.

During the experiment in March, the flow temperature was reduced, which led to a reduction in heat consumption. However, it can be observed that the decrease in heat consumption is related to the increase of temperature difference.

Decreasing heat consumption as the temperature difference rises, indicates a compensation for the temperature differences by increasing the mass flow rate and deliberate cost-increase of the system's performance, by increasing electricity consumption for water transportation in the system.

The mass flow rate changes during the pre-experiment and experiment periods indicate a logical decreasing trend in the mass flow rate due an increase in outdoor air temperatures. At the same time, there is an increase in the mass flow rate when the heat transfer supply flow temperature is reduced in order to reduce heat loss in the heat network. This is due to a decrease in the temperature difference. It is always important to have a higher temperature difference, mainly to obtain a low as possible back-flow temperature. However, the temperature difference during the experiment was much lower than during the pre-experiment in March. 
The link between the temperature difference of water supply and return flow and mass flow rate is illustrated in Fig. 9. A good correlation of data was observed during the pre-experiment in March $\left(R^{2}=0.96\right)$, which shows that, in the event of a decrease in the temperature difference, the flow rate increases. The rest of the data was not used for the analysis of regularities, as the data dispersion is large in March $\left(R^{2}=0.12\right)$ and February $\left(R^{2}=0.02\right)$.

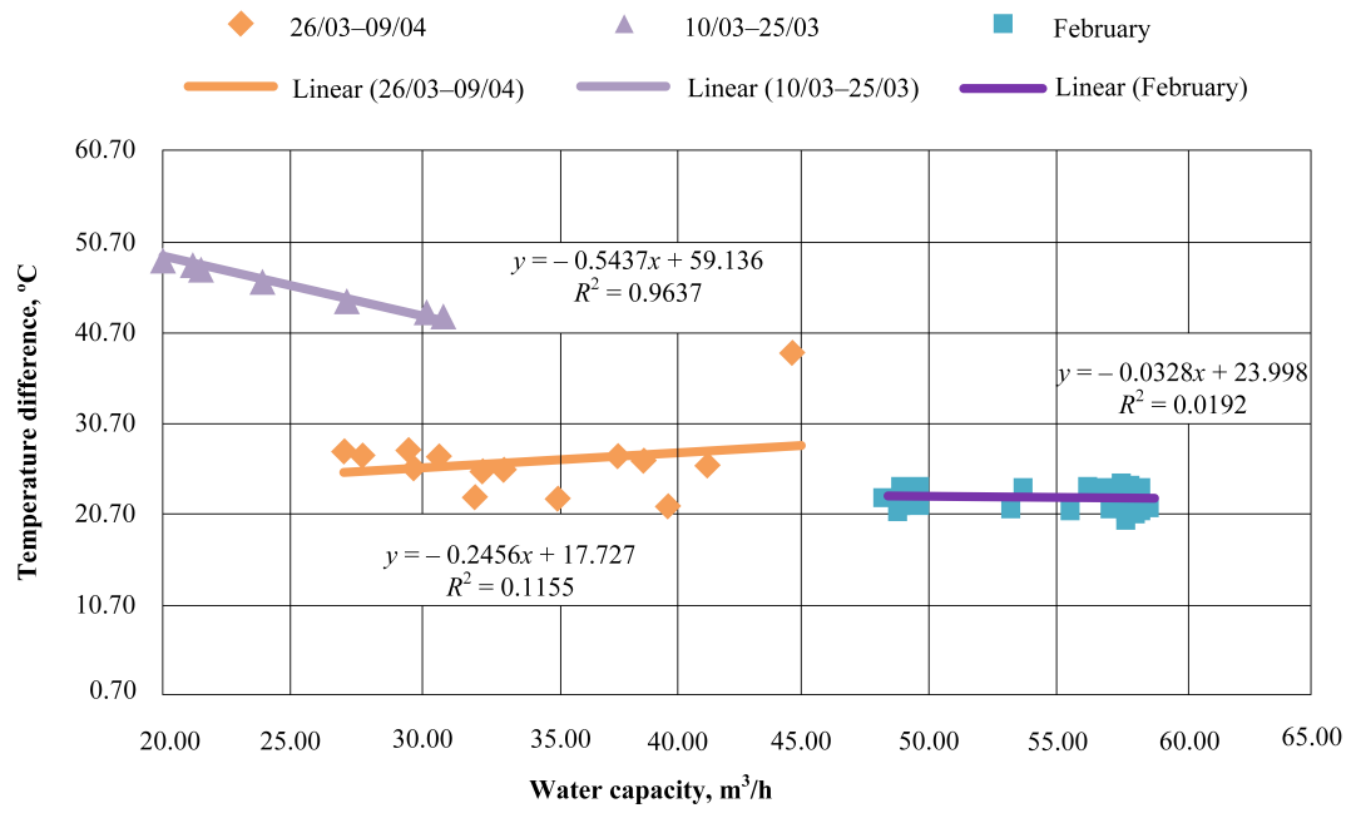

Fig. 9. Interaction of water temperature difference with mass flow rate in heat network.

\subsection{Empirical Model for Assessment of Energy Savings}

Heat consumption in buildings depends on the outdoor air temperature and the correlation of data is good during the pre-experiment in February $\left(R^{2}=0.76\right)$ and in March $\left(R^{2}=0.82\right)$, however, the correlation is best during the experiment $\left(R^{2}=0.93\right)$ (see Fig. 9). This means that these mathematical relationships can be used to express the heat consumption dependence on the outside temperature.

The empirical equation for determining heat consumption at the pre-experiment stage, for example, in March is as follows:

$$
Q_{1}=1.34-0.056 \cdot t_{\text {out }}
$$

where

$Q_{1} \quad$ Daily heat consumption at pre-experimental stage, $\mathrm{MWh} / \mathrm{day}$;

$t_{\text {out }} \quad$ Outdoor air temperature, ${ }^{\circ} \mathrm{C}$.

The empirical equation for determining heat consumption during an experiment is as follows: 


$$
Q_{2}=1.29-0.065 \cdot t_{\text {out }},
$$

where

$Q_{2} \quad$ Daily heat consumption during the experiment, MWh/day.

Reduction of the supply flow temperature by $20{ }^{\circ} \mathrm{C}$ has led to heat savings in the building, and the comfort of the building's inhabitants has not diminished. An empirical model for modelling heat savings, when the supply flow temperature is lowered, can be determined as follows:

$$
\begin{gathered}
Q_{1}-Q_{2}=(1.34-1.29)-(0.056-0.065) \cdot t_{\mathrm{out}}, \\
\delta Q=0.05+0.009 \cdot t_{\mathrm{out}},
\end{gathered}
$$

where $\delta Q$ is heat savings in one day by reducing the heat transfer supply flow temperature by $20^{\circ} \mathrm{C}, \mathrm{MWh} /$ day.

Eq. (4) and Eq. (5) present trend of changes in heat energy savings versus outdoor temperature in case of heat energy consumption in the building to cover needs of heating and hot water system. Therefore, it is important to reduce the supply flow temperature, analyse the nature of mathematical relations - the dependence of the heat consumption of the building on the outdoor air temperature (the higher the slope of the line, the greater the reduction in heat consumption).

\subsection{Economic Assessment}

With the introduction of $4^{\text {th }}$ generation heating system solutions, lowering the supply flow temperature, water mass flow rate in the system increases and electricity consumption increases. Therefore, $t_{\text {costs }}$ can increase and decrease depending on the set operating mode.

A methodology has been developed that allows estimating the total cost savings associated with the reduction of heat loss in the system by reducing the supply flow temperature, and increasing electricity consumption by increasing the water capacity in the DH system. Increase of water capacity creates growth of electricity consumption. The calculations consider that the ratio of the water capacity rate increase leads to an increase in electricity consumption in the cube.

It is possible to assess the total costs (savings and losses) in this particular case by applying the empirical Eq. (6):

$$
C=3.106 \ln \left(t_{\text {out }}\right)-4.25 \text {, }
$$

where $C$ is energy saving costs in case of reduction of supply temperature in DH system, EUR/MWh.

The total cost of the Kemeri building block is negative when the outdoor air temperature is below $4{ }^{\circ} \mathrm{C}$ (see Fig. 10). This means that reducing the supply flow temperature in this particular case has not produced the expected effect. Supply temperature can lead to economical savings in cases when the outdoor temperature is above $4{ }^{\circ} \mathrm{C}$. Data on current energy and electricity prices are used in the calculations: fuel is relatively cheap, but electricity is expensive. 


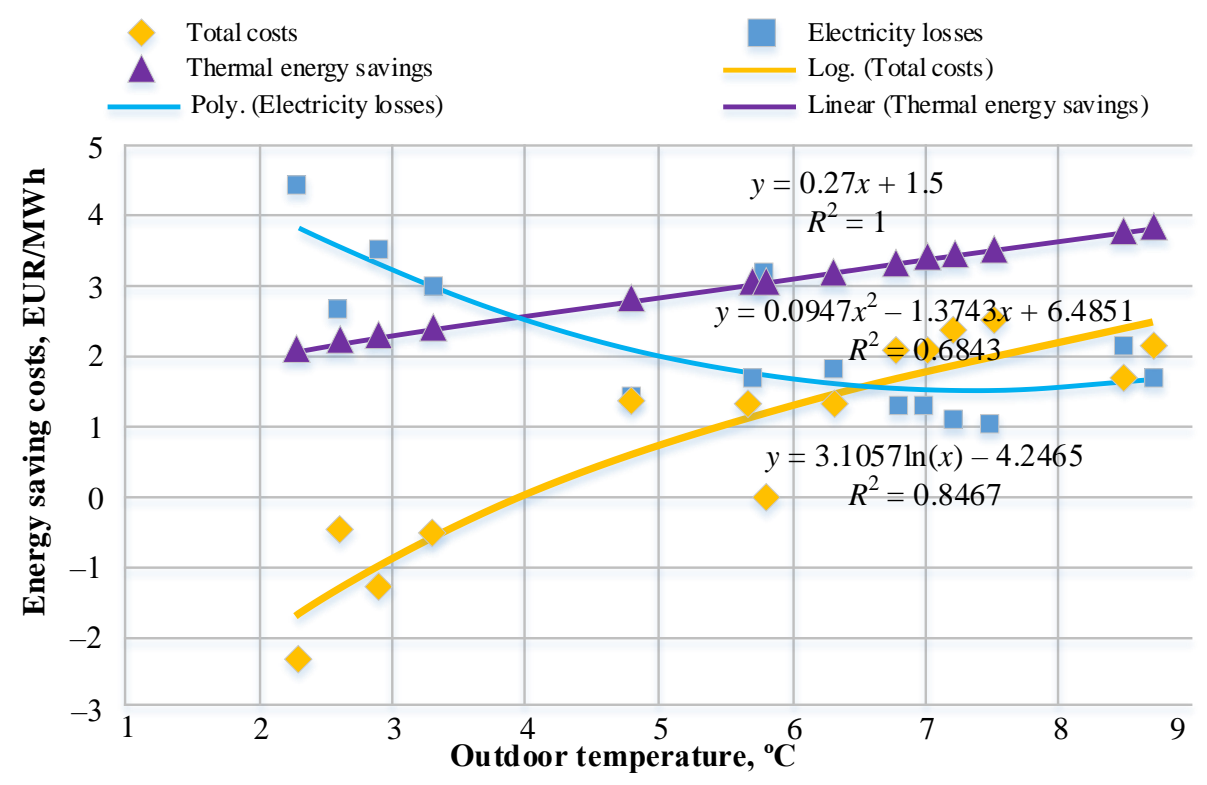

Fig. 10. Graph of cost evaluation.

The developed methodology is applicable in cases when it is necessary to predict the implementation of $4^{\text {th }}$ generation heat supply without large investments.

\section{Conclusions}

A methodology for analysing the feasibility of $4^{\text {th }}$ generation heat supply has been developed, where the supply flow temperature of the heating system is decreased. Technological options and reductions in heat consumption have been assessed using the empirical model during experiments. The empirical model shows that, when the heat consumer operates both the heating and hot water system, heat savings depend on outdoor temperature.

Based on experimental data, a methodology has been developed that allows estimating the total energy cost savings (including losses) of buildings associated with the reduction of heat loss in the system, by reducing the supply flow temperature, and increasing electricity consumption by increasing the mass flow rate in the heat network. The implementation of this methodology along with proper application can lead to a significant reduction of $\mathrm{CO}_{2}$ emissions, as well as save energy resources.

Further research should focus on analysing costs in different operating regimes, which would give more detailed information on the possible cost savings.

\section{ACKNOWLEDGEMENT}

This research is funded by the Ministry of Economics of the Republic of Latvia, project "Development of heat supply and cooling systems in Latvia", project No. VPP-EM-EE-2018/1-0002. 


\section{REFERENCES}

[1] European Commission. The revised energy efficiency directive. [Online]. Available at: https://ec.europa.eu/energy/en/topics/energy-efficiency/energy-efficiency-directive

[2] Buffa S., Cozzini M., D’Antoni M., Baratieri M., Fedrizzi R. 5th generation district heating and cooling systems: a review of existing cases in Europe. Renewable and Sustainable Energy Reviews 2009:104:504-522. doi:10.1016/j.rser.2018.12.059

[3] Schmidt D. Low Temperature District Heating for Future Energy Systems. Energy Procedia 2018:149:595-604. doi:10.1016/j.egypro.2018.08.224

[4] Chicherin S. Low-temperature district heating distributed from transmission-distribution junctions to users: energy and environmental modelling. Energy Procedia 2018:147:382-389. doi:10.1016/j.egypro.2018.07.107

[5] Li Y., Xia J., Su Y., Jiang Y. Systematic optimization for the utilization of low-temperature industrial excess heat for district heating. Energy 2018:144:984-991. doi:10.1016/j.energy.2017.12.048

[6] Arat H., Arslan O. Exergoeconomic analysis of district heating system boosted by the geothermal heat pump. Energy 2017:119:1159-1170. doi:10.1016/j.energy.2016.11.073

[7] Olsen P. K., Christiansen C. H., Hofmeister M., Svendsen S., Thorsen J. E. Guidelines for low-temperature district heating. EUDP 2010-II project Journal No. 64010-0479, 2014.

[8] Nord N., Nielsen E. K. L., Kauko H., Tereshchenko T. Challenges and potentials for low-temperature district heating implementation in Norway. Energy 2018:151:889-902. doi:10.1016/j.energy.2018.03.094

[9] Cai H., You S., Wang J., Bindner H. W., Klyapovskiy S. Technical assessment of electric heat boosters in low-temperature district heating based on combined heat and power analysis. Energy 2018:150:938-949. doi:10.1016/j.energy.2018.02.084

[10] Park B. S., Imran M., Hoon I. Y., Usman M. Thermo-economic optimization of secondary distribution network of low temperature district heating network under local conditions of South Korea. Applied Thermal Engineering 2017:126:117-133. doi:10.1016/j.applthermaleng.2017.07.080

[11] Li H., Wang S. J. Challenges in Smart Low-Temperature District Heating Development. Energy Procedia 2014:61:1472-1475. doi:10.1016/j.egypro.2014.12.150

[12] Yang X., Svendsen S. Achieving low return temperature for domestic hot water preparation by ultra-low-temperature district heating. Energy Procedia 2017:116:426-437. doi:10.1016/j.egypro.2017.05.090

[13] Østergaard D., Svendsen S. Space heating with ultra-low-temperature district heating - a case study of four single-family houses from the 1980s. Energy Procedia 2017:116:226-235. doi:10.1016/j.egypro.2017.05.070

[14] Latosov E., Volkova A., Siirde A., Kurnitski J., Thalfeldt M. Methodological Approach to Determining the Effect of Parallel Energy Consumption on District Heating System. Environmental and Climate Technologies 2017:19(1):5-14. doi:10.1515/rtuect-2017-0001

[15] Mediastika C. E., Hariyono J. Wall Cladding Effects and Occupants' Perception of Indoor Temperature of Typical Student Apartments in Surabaya, Indonesia. Environmental and Climate Technologies 2017:20(1):51-66. doi:10.1515/rtuect-2017-0010

[16] Albatayneh A., Alterman D., Page A., Moghtaderi B. The Significance of Building Design for the climate. Environmental and Climate Technologies 2018:22(1):165-178. doi:10.2478/rtuect-2018-0011

[17] Lund H., et al. The status of 4th generation district heating: Research and results. Energy 2018:164:147-159. doi:10.1016/j.energy.2018.08.206

[18] Im Y-H., Liu J. Feasibility study on the low temperature district heating and cooling system with bi-lateral heat trades model. Energy 2018:153:988-999. doi:10.1016/j.energy.2018.04.094

[19] Sameti M., Haghighat F. Optimization of 4th generation distributed district heating system: Design and planning of combined heat and power. Renewable Energy 2019:130:371-387. doi:10.1016/j.renene.2018.06.068

[20] Tunzi M., Østergaard D. S., Svendsen S., Boukhanouf R., Cooper E. Method to investigate and plan the application of low temperature district heating to existing hydraulic radiator systems in existing buildings. Energy 2016:113:413-421. doi:10.1016/j.energy.2016.07.033 